\title{
COMPARISON OF DIFFERENTIAL AGGLUTINATION TITRE (D.A.T.) IN JUVENILE AND ADULT RHEUMATOID ARTHRITIS
}

\author{
BY \\ E. G. L. BYWATERS, MARY E. CARTER, AND F. E. T. SCOTT \\ From the Rheumatism Research Unit, Medical Research Council, \\ Canadian Red Cross Memorial Hospital, Taplow
}

In the preceding paper (Bywaters, Carter, and Scott, 1959), it was shown that the Rose-Waaler test (positive in about 50 to 70 per cent. of adult rheumatoid arthritis cases) is frequently negative in childhood arthritis (Still's disease). This has also been remarked by others (Pike, Sulkin, and Coggeshall, 1955; Alexander and de Forest, 1954; Ziff, 1957), although by the inhibition technique 95.8 per cent. are positive (McEwen, Ziff, Carmel, Di Tata, and Tanner, 1958).

This raises the possibility that Still's disease is different from the rheumatoid arthritis seen typically in adults, as Still (1897) originally postulated. To provide further data pertinent to this, we have estimated the Rose-Waaler titre over a period of several years in a series of over 200 children and this report compares the titre in 142 juvenile cases followed for a minimum of 4 years with an adult group of rheumatoid arthritis patients. All sera were tested by one of us (F.E.T.S.) by the method described in the previous paper (Bywaters and others, 1959).

\section{Material}

The juvenile series of 142 patients is defined in the preceding paper. The adult series consists of 140 patients followed for at least 4 years, ninety from Hammersmith Hospital and fifty from Taplow, who fulfil the same criteria as those used for the juvenile group; four patients had less than four joints involved; three had three joints involved, and one had one joint only involved, but diagnosis was confirmed by synovial biopsy in these four cases.

The adults are thus comparable with the juvenile series except that single or infrequent Rose tests were performed. This difference is of no importance in analysing all tests according to decade (Figs 1 and 2), but would affect a comparison of patients according to decade, taking the Taplow juvenile and adult group together by decade at onset. For this reason, in tabulations subsequent to Figs 1 and 2, only the result of the first D.A.T. is taken into account.

However, for the purpose of comparing the D.A.T. titres at various decades, we could not include the ninety Hammersmith adults reported as positive or negative only, and there were thus too few adults in some of the decade groups. Thus, for Figs 1 and 2, 21 adults from Taplow were added (making a total of 71 adults and 142 children). These 21 patients were similar to the larger group of fifty Taplow adults except that they had not been followed for 4 years. They could not therefore be used for correlation of clinical phenomena shown over a 4-year period with the first D.A.T., which is the subject of Tables III and IV, and Figs 3, 4, and 5.

The functional state of the patient is graded from I to $\mathrm{V}$ :

$\begin{array}{rll}\text { Grade } & \text { I } & \text { Helpless } \\ \text { II } & \text { Chair/bed existence } \\ \text { III } & \text { Moderate limitation of function } \\ \text { IV } & \text { Slight limitation of function } \\ \text { V } & \text { No limitation of function }\end{array}$

\section{Results}

Table I (overleaf) compares the juvenile and adult cases in regard to sex, interval between onset and admission to hospital, and result of first Rose-Waaler test. Females preponderate in the adult series and juvenile rheumatoid arthritis is less frequently sero-positive.

Fig. 1 (overleaf) shows a progressive increase in positive D.A.T. results with lateness of onset, whatever definition of "positivity" is adopted. The most valid curve is the dotted line which shows only the result of the first test performed. 
TABLE I

COMPARISON OF JUVENILE AND ADULT SERIES, BY SEX, DURATION OF DISEASE

FROM ONSET, AND RESULT OF FIRST D.A.T.

\begin{tabular}{|c|c|c|c|c|c|c|c|c|}
\hline \multirow{2}{*}{\multicolumn{3}{|c|}{ Total No. of Patients }} & \multicolumn{2}{|c|}{ Sex } & \multicolumn{2}{|c|}{ First Examined } & \multicolumn{2}{|c|}{$\begin{array}{l}\text { Patients with D.A.T } \\
\text { Positive at First Test }\end{array}$} \\
\hline & & & Male & Female & $\begin{array}{l}\text { "Late" >1 yr } \\
\text { flom Onset }\end{array}$ & $\begin{array}{l}\text { "Early" <1 yr } \\
\text { from Onset }\end{array}$ & No. & Pel cent \\
\hline Adult & $\ldots$ & 140 & 37 & 103 & 71 & 69 & 70 & 50 \\
\hline Juvenile & $\ldots$ & 142 & 57 & 85 & 75 & 67 & 19 & $13 \cdot 4$ \\
\hline
\end{tabular}

86

72

16

II

13

NUMBER OF PATIENTS IN EACH DECADE OF ONSET

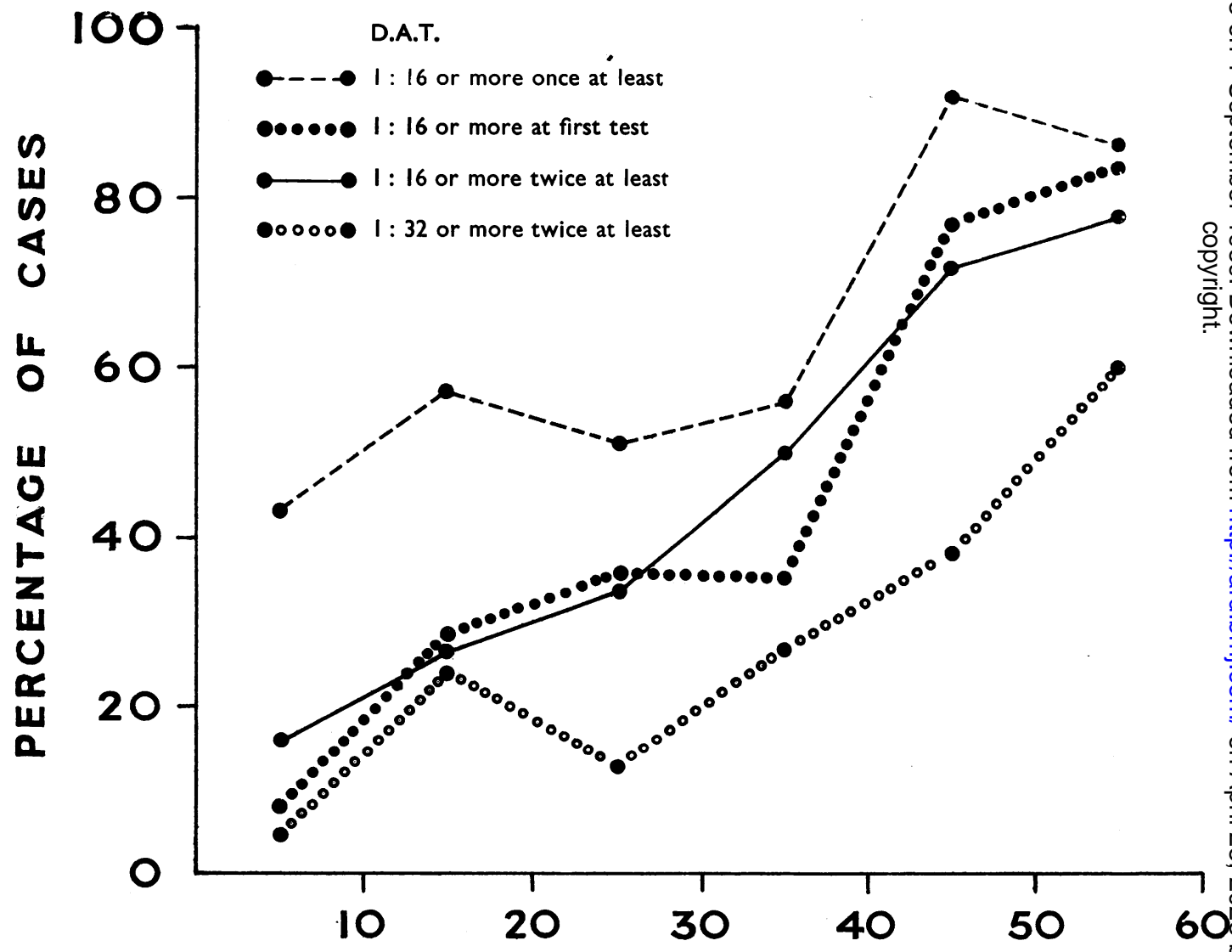

\section{AGE AT ONSET, BY DECADE}

Fig. 1.-Correlation of D.A.T. results with age at onset, taking four levels of "positivity". 
Fig. 2 shows the percentage distribution by titre of all estimations done on patients in each decade.
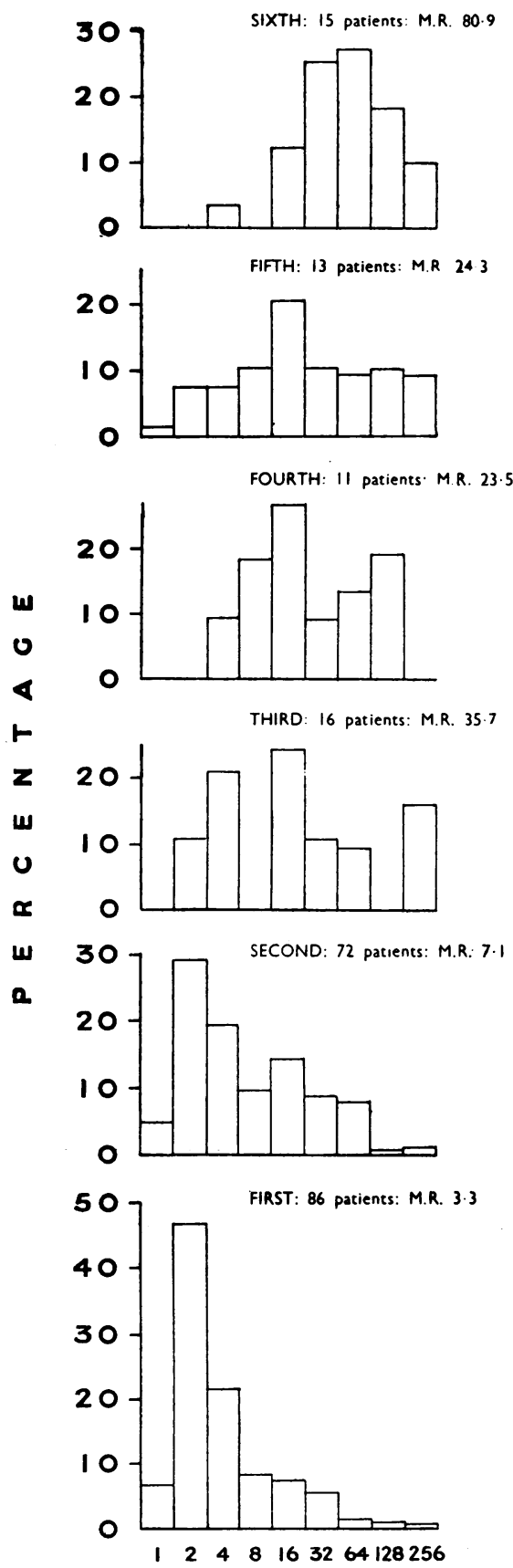

D.A.T. RECIPROCALS

Fig. 2.-Percentage distribution of titre in each of six decades. (M.R. = mean reciprocal).
It will be seen that there is a progressive increase in the frequency of high titres with age. The reciprocal of the mean (logarithmic) titre at each decade ("M.R." on the graph) also shows a progressive rise apart from two points. The number of patients in each decade is the same as in Fig. 1.

The' numbers of patients in each decade and the D.A.T. results given in Table II apply to all the subsequent Figures and Tables.

TABLE II

DISTRIBUTION OF 282 PATIENTS IN DECADES AND OF FIRST POSITIVE D.A.T.S

\begin{tabular}{lr|c|c|c|c|c|c|c}
\hline Decades.. & $\ldots$ & $0-9$ & $10-19$ & $20-29$ & $30-39$ & $40-49$ & $50-59$ & $60+$ \\
\hline $\begin{array}{l}\text { No. in Each } \\
\text { Decade }\end{array}$ & $\ldots$ & 86 & 71 & 20 & 30 & 28 & 32 & 15 \\
\hline $\begin{array}{l}\text { First D.A.T. } \\
\begin{array}{l}\text { Positive (1:16 } \\
\text { or More) }\end{array}\end{array}$ & 7 & 18 & 7 & 14 & 15 & 20 & 8 \\
\hline
\end{tabular}

Since a rash is one of the more prominent features of the juvenile disease (Isdale and Bywaters, 1956) and nodules are more prominent in older patients (Bywaters, Glynn, and Zeldis, 1958), we have studied these two features, together with the improvement in functional state over the 4 years, as reflecting prognosis.

Fig. 3 (overleaf) shows the percentage of D.A.T. positive and D.A.T. negative patients in each decade, who showed a rash. The total percentage of patients with a rash in each decade is indicated by the dotted line. The incidence of rash falls rapidly with age, and there is no correlation with the D.A.T. response.

Fig. 4 (overleaf) similarly shows the percentage of all D.A.T. positive patients and of all D.A.T. negative patients in each decade who showed nodules. It will be seen that at each decade a higher proportion of the D.A.T. positive group than of the D.A.T. negative group had nodules. The total percentage of patients with nodules in each decade is indicated by the dotted line. The incidence of nodules increases with age.

Prognosis.-This appears better in the young, because almost 88 per cent. improved over the 4-year period as against 50 per cent. in adults. Tables III and IV (overleaf) show the details of improvement or deterioration of 136 "early" patients out of the total 282 , divided into four age groups at onset, and also compares sero-positive (at least one positive D.A.T.) with sero-negative patients. The mean functional status when first seen and at the fourth follow-up is given for the various age groups. 
IST D.A.T. I:16 OR MORE
D.A.T. I:8 OR LESS

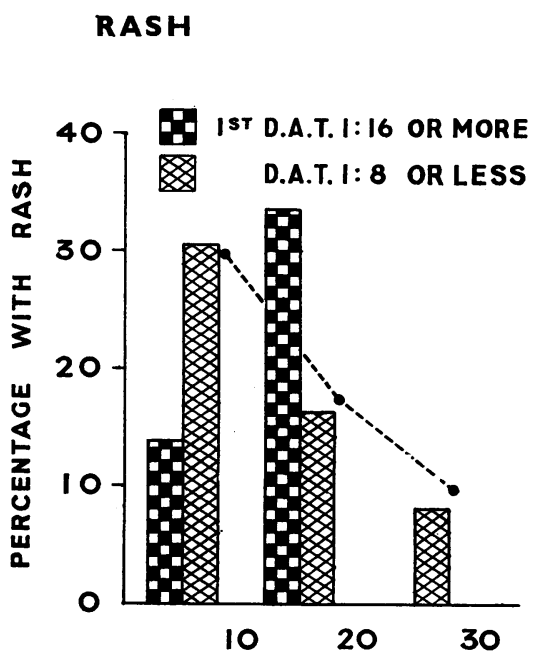

AGE AT ONSET, BY DECADE

Fig. 3.-Correlation of rash with D.A.T. Percentage of patients in each decade with rash, according to D.A.T. titre, in a series of 282 cases. Dotted line indicates total percentage of patients with rash in each decade.

TABLE III

CHANGE IN FUNCTIONAL STATUS AT FOLLOW-UP IN EARLY CASES (CHILDREN AND ADULTS) IN WHICH THE FIRST D.A.T. WAS POSITIVE

\begin{tabular}{|c|c|c|c|c|c|}
\hline Age at Onset (decade) & . & $0-9$ & $10-19$ & $20-49$ & $50+$ \\
\hline \multirow[t]{2}{*}{$\begin{array}{l}\text { Percentage Change } \\
\text { in } \\
\text { Functional Status }\end{array}$} & $\begin{array}{l}\text { Improved } \\
\text { Unchanged }\end{array}$ Worse & $\begin{array}{r}100 \\
0 \\
0\end{array}$ & $\begin{array}{r}90 \\
0 \\
10\end{array}$ & $\begin{array}{l}16 \cdot 6 \\
16 \cdot 6 \\
50\end{array}$ & $\begin{array}{l}36 \cdot 8 \\
21 \cdot 1 \\
12 \cdot 2\end{array}$ \\
\hline & Total .. & 3 & 10 & 12 & 19 \\
\hline $\begin{array}{c}\text { Mean Functional } \\
\text { Status }\end{array}$ & $\begin{array}{l}\text { When First } \\
\text { Seen } \\
\text { At Fourth } \\
\text { Follow-up. }\end{array}$ & $\begin{array}{l}1 \\
4 \cdot 3\end{array}$ & $\begin{array}{l}2 \cdot 8 \\
4 \cdot 7\end{array}$ & $\begin{array}{l}3 \cdot 8 \\
4 \cdot 1\end{array}$ & $\begin{array}{l}3 \cdot 9 \\
4 \cdot 0\end{array}$ \\
\hline
\end{tabular}

There is little difference in prognosis between the "positive" and "negative" groups.

Fig. 5 (opposite) illustrates the reason for the apparently greater improvement of the juvenile group. When first seen, those in the younger decades had a low functional status and improved a great deal during the 4 years. Those in the older decades started with a higher functional level and
NODULES

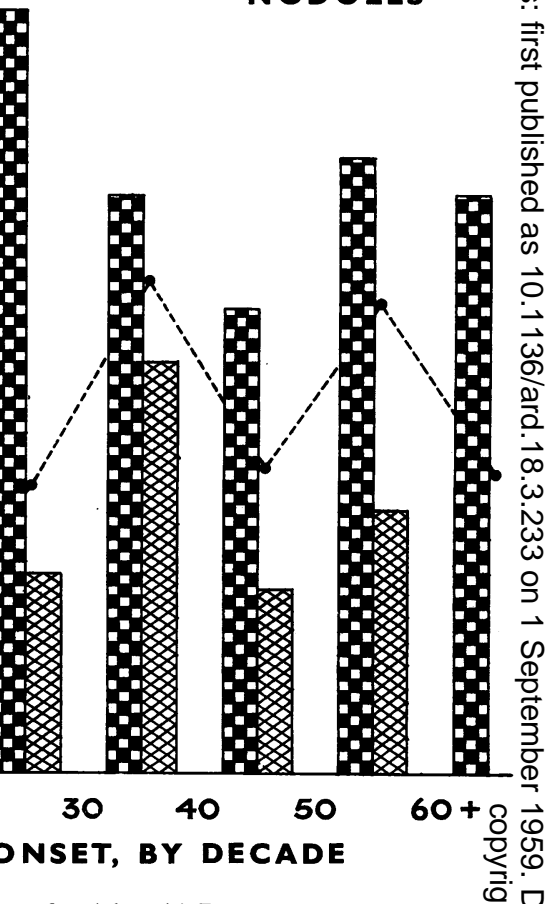

Fig. 4.-Correlation of nodules with D.A.T. Percentage of patie in each decade with nodules, according to D.A.T. titre, in a series of 282 cases. Dotted line indicates total percentage of patients with nodules in each decade.

\section{TABLE IV}

CHANGE IN FUNCTIONAL STATUS AT FOLLOW-UP IN EARLY CASES (CHILDREN AND ADULTS) IN WHICH THEFIRST D.A.T. WAS NEGATIVE

\begin{tabular}{|c|c|c|c|c|c|}
\hline Age at Onset (decade) & .. & $0-9$ & $10-19$ & $20-49$ & $50+\frac{\varrho}{2}$ \\
\hline \multirow{2}{*}{$\begin{array}{l}\text { Percentage Change } \\
\text { in } \\
\text { Functional Status }\end{array}$} & $\begin{array}{l}\text { Improved } \\
\text { Unchanged } \\
\text { Worse }\end{array}$ & $\begin{array}{l}86 \\
5 \cdot 5 \\
8 \cdot 5\end{array}$ & $\begin{array}{l}81 \cdot 5 \\
18 \cdot 5 \\
0\end{array}$ & $\begin{array}{r}56 \\
38 \\
6\end{array}$ & $\begin{array}{r}77 \\
0 \\
23\end{array}$ \\
\hline & Total .. & 36 & 27 & 16 & 13 \\
\hline $\begin{array}{c}\text { Mean Functional } \\
\text { Status }\end{array}$ & $\begin{array}{l}\text { When First } \\
\text { Seen } \\
\text { At Fourth } \\
\text { Follow-up. }\end{array}$ & $\begin{array}{l}2 \cdot 0 \\
4 \cdot 4\end{array}$ & $\begin{array}{l}3 \cdot 1 \\
4 \cdot 7\end{array}$ & $\begin{array}{l}4 \cdot 2 \\
4 \cdot 7\end{array}$ & $\begin{array}{l}3 \cdot 6 \text { 음 } \\
4 \cdot 2 \frac{7}{0}\end{array}$ \\
\hline
\end{tabular}

N

achieved almost the same functional state at the fourth year.

The reason for the marked difference in functional status when first seen between juveniles and adults may be due to the fact that most adults haveo responsibilities, either in employment or in looking after a home and family, and therefore keep active? + longer; children, on the other hand, are nearly 


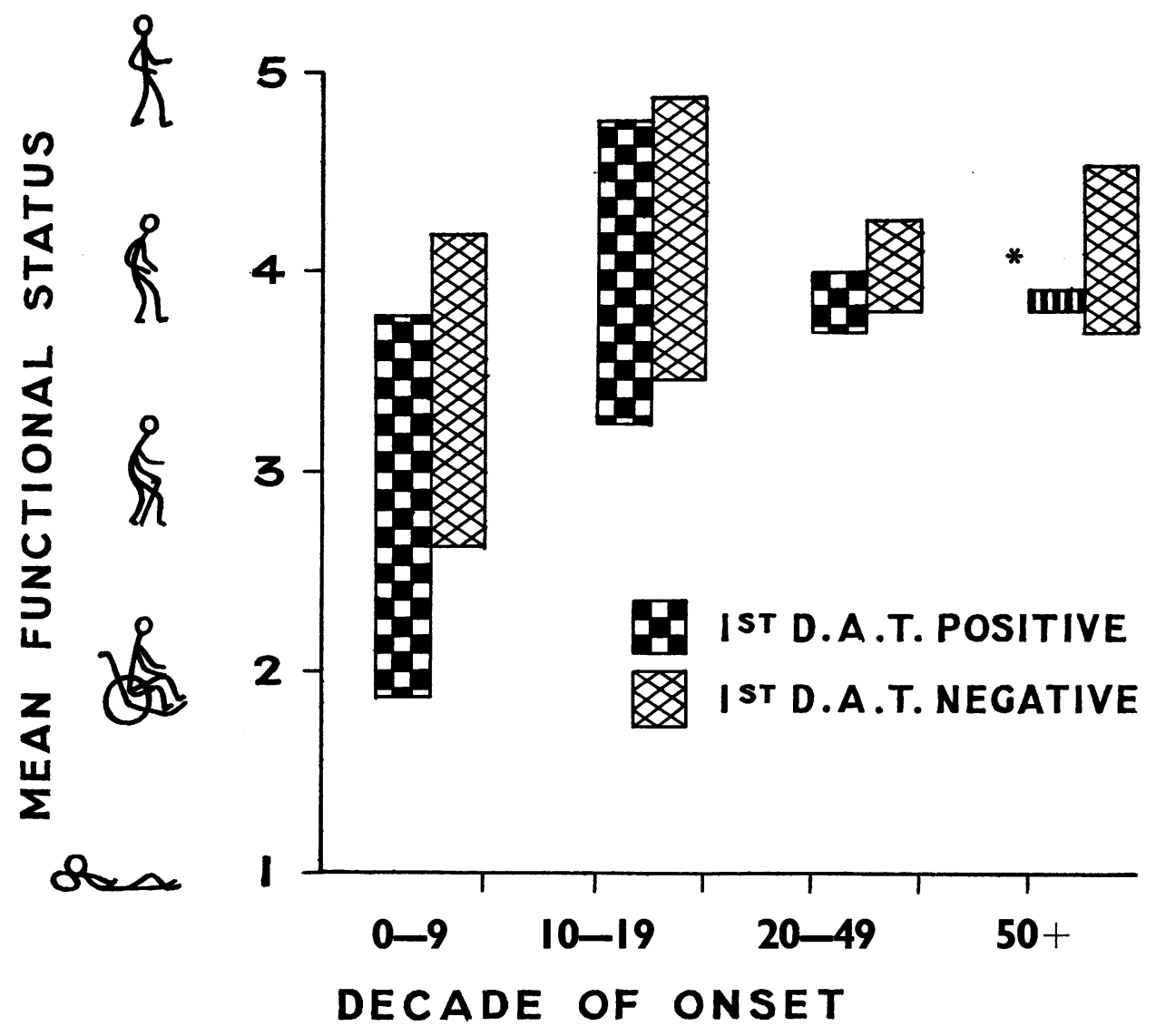

Fig. 5.-Improvement or deterioration* of mean functional status over a 4-year period, according to decade of onset and D.A.T. in a series of 282 cases.

always put to bed when the early signs of illness appear. Our experience in this Unit has been that prolonged rest and immobilization, particularly in children, reduces them to a condition of stiffness and eventual ankylosis, with a consequent low functional state.

\section{Summary}

140 adult patients with rheumatoid arthritis were compared with the 142 juvenile patients used for the study described in the previous paper (Bywaters, Carter, and Scott, 1959). Both groups were comparable as regards criteria and duration of follow-up, but fewer D.A.T.s were done in the adult group; therefore only the first D.A.T. was used for comparison between the two groups of patients. A partially different group of adults (71) was used in compiling Figs 1 and 2, which show that the D.A.T. becomes progressively positive with greater age at onset, and that there is a progressive increase in the frequency of high titres with age. A marked difference is seen in the D.A.T. response of the adult and juvenile group, 50 per cent. of adults being seropositive on first testing compared with 13.4 per cent. of juveniles. A progressive change with age in D.A.T. response and incidence of rash and nodules is also seen.

Improvement is more marked in the young, because children tend to start at a lower functional grade than adults. There is no significant difference in prognosis between the sero-positive and seronegative groups in either children or adults.

Since there is progressive change with age in the clinical features here investigated, we conclude that there is not yet sufficient evidence to justify the view that rheumatoid arthritis and Still's disease are 
separate diseases. It is suggested that the differences are due to age alone.

We are most grateful to Dr. E. Lewis-Faning for his detailed criticisms and suggestions in regard to the presentation of these results.

\section{REFERENCES}

Alexander, R., and de Forest, G. K. (1954). Amer. J. Med., 16, 191 Bywaters, E. G. L., Glynn, L. E.. and Zeldis, A. (1958). Ann. rheum. Dis., 17, 278.

Isdale, I. C., and Bywaters, E. G. L. (1956). Quart. J. Med., 25, 377. McEwen, C., Ziff, M., Carmel, P., DiTata, D., and Tanner, M. (1958). McEwen, C., Ziff, M., Carmel, $P$.

Pike, R. M., Sulkin, S., E., and Coggeshall. H. C. (1955). Med. Clin. N. Amer., 39, 379.

Still, G. F. (1897). Med.-chir. Trans., 80, 47.

Ziff, M. (1957). J. chron. Dis., 5. 644.

Comparaison des titres d'agglutination différentielle (D.A.T.) dans l'arthrite rhumatismale ïuvénile et adulte

\section{RÉSUMÉ}

On compara 140 cas d'arthrite rhumatismale adulte à 142 cas juvéniles, ayant déjà fait l'objet d'un travail antérieur (Bywaters, Carter, et Scott, 1959). Les deux groupes sont comparables en ce qui concerne les critères diagnostiques et la durée d'observation, mais le D.A.T. fut déterminé moins souvent chez les adultes; pour cette raison on ne s'est servi que de la première détermination pour comparer les deux groupes. On prit un groupe partiellement différent d'adultes (71) pour compiler les fig. 1 et 2 , montrant que la positivité du D.A.T. augmente en fréquence avec l'âge de début et le titre tend à monter avec l'âge du malade. On nota une différence marquée dans le D.A.T. entre les deux groupes, $50 \%$ des adultes ayant été séro-positifs à la première détermination. comparé à $13,4 \%$ des jeunes. On observa aussi des altérations progressives, selon l'âge, du D.A.T. et de la fréquence de l'exanthème et des nodules.

Les améliorations furent plus marquées chez les jeunes, parce que les enfants tendent à commencer à un grade fonctionnel plus bas que les adultes. Il n'y eut pas de différence pronostique significative entre les groupes séro-positifs et séro-négatifs, jeunes ou adultes.

En raison des altérations progressives des traits cliniques selon l'âge, observées dans ce travail, on conclut qu'il n'y a pas de preuves suffisantes pour justifier le $\vec{\sim}$ point de vue que l'arthrite rhumatismale et la maladie de $\overrightarrow{0}$ Still soient des maladies séparées. On suggère que les différences notées ne seraient dues qu'à l'âge.

Comparación de cifras de aglutinación diferencial (D.A.T.) en la artritis reumatoide juvenil y adulta

\section{SUMARIO}

Se compararon 140 casos de artritis reumatoide adulta $\overrightarrow{0}$ con 142 casos juveniles, objetos de un trabajo anterior (Bywaters, Carter y Scott, 1959). Ambos grupos se $\vec{\omega}$ parecen respecto a los criterios diagnósticos y al período de observación, pero el D.A.T. fué determinado con menos frecuencia en los adultos; por esta razón, para? comparar los grupos entre si, se tomó sólo la primera $\vec{\infty}$ determinación. Se escogió un grupo parcialmente $\omega$ diferente de adultos (71) par componer las Figs. 1 y 2. N revelando que la positividad de D.A.T. aumenta en frecuencia con la edad de comienzo de la enfermedad yo que sus cifras tienden a subir con la edad del enfermo. Se notó una diferencia marcada en la D.A.T. entre los dosgrupos, un $50 \%$ de los adultos y sólo un $13,4 \%$ de los jovenes siendo sero-positivos a la primera determinación $\mathbb{D}$ Se observaron también alteraciones progresivas, según苘 la edad, de la D.A.T. y de la frecuencia de exantemas y de nódulos.

Mejorías fueron más acentuadas en los jóvenes, ya que niños tienden a empezar con un grado funcioral $\vec{c}$ más bajo que los adultos. No hubo diferencia pron鸟tica significativa entre los grupos sero-positivos y sero-negativos tanto jóvenes como adultos.

En vista de las alteraciones progresivas de los rasgơs clínicos con la edad, observadas en este trabajo, se concluye que no hay datos suficientes para justificar la hipótesis, que la artritis reumatoide y la enfermedad deo Still sean enfermedades separadas. Se sugiere que las diferencias notadas se deberían sólo a la edad. 
and claims that the results were excellent in 73 per cent., good in 17 per cent., and poor in 10 per cent.

[This paper fails to convince. In tennis elbow, for example, which falls within the definition of triggerpoint phenomenon, pain can also be elicited by putting the forearm extensors into tension; moreover, in a proportion of such cases (especially if the trouble is bilateral) in spite of local signs and symptoms the ultimate cause is found to lie in the cervical spine.]

\section{Preiskel.}

Rheumatism in Cotton Operatives. LAWRENCE, J. S. (1961). Brit. J. industr. Med., 18, 270. 2 figs, 5 refs.

The incidence of rheumatism in a sample of 117 male and 228 female cotton workers aged 45 and over was compared with the incidence in a similar number of control subjects who had never worked in cotton and who were randomly selected from an urban and rural population. More of the control subjects ( 89 per cent. of males and 85 per cent. of females) than of the cotton workers (73 and 74 per cent. respectively) gave a history of symptoms of rheumatism and of loss of work because of rheumatism. On the other hand the male cotton workers had more severe osteo-arthrosis in the finger and thumb joints than the controls, as assessed by radiography; it is suggested that this may be due to continuous minor traumata. The authors conclude that "in view of the relatively benign nature of the disease found in cotton operatives, preventive measures are not indicated".

\section{John Pemberton.}

Possibilities of Physiotherapy. (Möglichkeiten der PhysioTherapie.) Hirschreld, P. F., and Longton, J. E. (1961). Z. Rheumaforsch., 20, 416. Bibl.

Contribution to the Problem of "Rheumatic" Back Pains. (Beitrag zum Problem der "rheumatischen" Rückenschmerzen.) KelLeR, G. (1961). Z. Rheumaforsch., 20, 423.
Nocturnal Painful Acroparaesthesia and the Carpal Tunnel Syndrome. (Acroparestesi dolorose notturne e sindrome del canale del carpo.) Fumagalli, E. (1961). Reumatismo, 13, 282. 3 figs, bibl.

Use of Baytinal in the Stretching of Contractures of the Joints. (Úber die Anwendung von Baytinal bei der Streckung von Gelenkkontrakturen.) RIESZ, E., and CsÁzÁR, Gy. (1961). Z. Rheumaforsch., 20, 436. 3 refs.

A Clinical Type of Sciatic Neuralgia, "Sciatic Sympathalgia". (Une form clinique de la névralgie sciatique, "la sympathalgie sciatique".) DEsLousPAOLI, M. (1961). Rhumatologie, 13, 219.

Sympathetic Syndromes in Rheumatology and their Treatment with Hydergine. (Les syndromes sympathiques en rhumatologie et leur traitement par 1-Hydergine.) LANGERON, L., VINCENT, G., and GARY, R. (1961). Rhumatologie, 13, 209.

Use of a New Combination of Drugs and Steroids in the Treatment of Rheumatic Diseases. (El empleo de una nueva asociación con esteroides en el tratamiento de las enfermedades reumáticas.) BARCELó, P., and Santamaría, A. (1961). Rev. esp. Reum., 9, 98. 3 figs.

Comprehensive Medical Care for Handicapped Children. Glaser, H. H., LyNN, D. B., and Harrison, G. S. (1961). Amer. J. Dis. Child., 102, 344.2 figs, 11 refs.

Musculoskeletal Complaints in an Industry. Annual Complaint Rate and Diagnosis, Absenteeism, and Economic Loss. Brown, R., and LINGG, C. (1961). Arthr. and Rheum., 4, 283. 1 fig., 14 refs.

Dental Treatment of Rheumatic Patients. (Traitement dentaire des rhumatisants.) PAYER, A. G. (1961). Méd. et Hyg., 19, 347.

\section{CORRIGENDUM}

In the paper entitled "Comparison of Differential Agglutination Titre (D.A.T.) in Juvenile and Adult Rheumatoid Arthritis", by E. G. L. Bywaters, Mary E. Carter, and F. E. T. Scott (Ann. rheum. Dis., 1959, 18, 233), the following correction should be made to Table III, p. 236:

\begin{tabular}{c|c|c|c|c|c}
\hline \multicolumn{2}{c|}{ Age at Onset (decade) } & $0-9$ & $10-19$ & $20-49$ & $50+$ \\
\hline \multirow{2}{*}{\begin{tabular}{c|c|c|c} 
Percentage Change \\
in
\end{tabular}} & Improved & 100 & 90 & 50 & 47 \\
Functional Status & Unchanged & 0 & 0 & 33 & 26 \\
& Worse & 0 & 10 & 17 & 26 \\
\cline { 2 - 6 } & Total .. & 3 & 10 & 12 & 19 \\
\hline
\end{tabular}

